\title{
Developing an Organizational Typology of Criminals in the Meat Supply Chain
}

\author{
by Manning, L., Smith, R. and Soon, J.M.
}

Copyright, Publisher and Additional Information: Publishers version distributed under the terms of the Creative Commons Attribution License:

https://creativecommons.org/licenses/by/4.0/

DOI: 10.1016/j.foodpol.2015.12.003

Harper Adams

University

Manning, L., Smith, R. and Soon, J.M. 2015. Developing an Organizational Typology of Criminals in the Meat Supply Chain. Food Policy, 59, pp. 44-54 


\title{
Developing an Organizational Typology of Criminals in the Meat Supply Chain
}

\author{
Louise Manning ${ }^{1}$, Robert Smith ${ }^{2}$ and Jan Mei Soon ${ }^{3}$ \\ ${ }^{1}$ Royal Agricultural University, Stroud Road, Cirencester, UK GL7 6JS \\ ${ }^{2}$ UWS School of Business and Enterprise, Dumfries \\ ${ }^{3}$ International Institute of Nutritional Sciences and Applied Food Safety Studies, School of \\ Sport and Wellbeing, University of Central Lancashire, Preston PR1 2HE UK
}

\begin{abstract}
The European Horsemeat Scandal of 2013 highlighted the increasing organization and sophistication of the contemporary food criminal. This study aims to develop a more sophisticated understanding of the typology of the food criminal in terms of their modus operandi and how individuals and organized crime groups develop criminal business models and networks in the context of meat supply. This research initiates a synthesized literature review across the seemingly disparate academic disciplines of food and agricultural policy, business theory and criminology in order to characterize the modes of operation at work in such networks. A conceptual framework is developed that considers the actors and drivers involved in criminal activity using the meat supply chain as an example.
\end{abstract}

\section{Key words}

Meat, crime, actors, drivers, networks, perpetrators

\section{Introduction}

The European Horsemeat (or Horsegate) Scandal of 2013 has brought the issue of food fraud to the fore and has highlighted the 'dark side' of the meat trade. The scandal evidenced a widespread contempt for consumers and their ability to make informed choices especially with regard to the species of animal they consumed. To the active food fraudster in the meat supply chain, animals are trafficked as a source of protein in exchanged for financial gain. The animal's slaughter, processing and eventual consumption in homes and restaurants are all necessary stages in an 
extended illicit food supply chain. Yet, our understanding of the modus operandi and modus vivendi of the food fraudster in the meat and processed food supply chain from an organizational and motivational perspective is minimal. Consequentially, there is little critical academic study of the relationship between supply chain organization and food criminals. Therefore in this paper, we make an attempt to bridge the gap by describing, explaining and theorizing the challenge of mitigating the activities of those individuals, and the associated criminal and commercial organizations.

In this type of food fraud the animals are commoditized, often being stolen or illegally slaughtered through organized activities, including the poaching of game animals, prior to entering the supply chain, (Budiansky 1999, FSA, nd). In the exploitation of animals for pure profit we consider the issue of business ethics (Desmond 2010; Jones et al. 2005) as otherwise inappropriate protein sources, enters into the supply chain and might be fraudulently used to

substitute for more expensive animal protein (Ballin 2010; Williams 2008). In addition to fraudulent practice, this, in the instance of pig protein, also renders the meat product haram (not permitted and unlawful) in terms of the halal meat supply chain (Nakyinsige et al. 2012). In connection with the United Kingdom (UK) Foot and Mouth Disease (FMD) outbreak of 2001, suspicions that meat had been illegally imported, illegal movements of sheep, to the spreading of disease with criminal intent, criminal compensation claims, and so on, underpinned the metaphor and the reality of criminality which were intertwined at almost every turn in the FMD narrative (Nerlich et al. 2004: 104; NAO 2002).

\section{The concept of food fraud and wider food crime}

Fraud involving food is an ancient practice particularly whenever there is the lure of an easy profit. There are always people ready and willing to exploit others (Gallagher and Thomas 2010; Shears 2010). We are concerned here with the deliberate contamination of food for malicious intent or criminal gain (Manning et al. 2005). Economically motivated adulteration (EMA) has been described as "The fraudulent, intentional substitution or addition of a substance in a product 
for the purpose of increasing the apparent value of the product or reducing the cost of its production, i.e. for economic gain" (See Spink and Moyer 2013: 3). Collectively, food fraud encompasses the deliberate and intentional substitution, addition, tampering, or misrepresentation of food, food ingredients, or food packaging; or false or misleading statements made about a product for economic gain (Spink and Moyer 2011a; 2011b; Grundy et al. 2012). Intentional food crime also encompasses food defense consisting of the set of actions taken in response to the intentional acts designed to cause harm. Food industry malpractices such as fraud are often driven by the need to compete with other businesses that perhaps have better economies of scale and to compete with corporate manufacturers, food service companies and food retailers who increasingly operate as oligopolies. The profits from food supply chain fraud have been described as being comparable to cocaine trafficking, with fewer risks (Mueller 2007). As an example the 'Eurovet scandal' in which a businessman/ farmer set up a company to import and sell unlicensed veterinary medicines earned the perpetrators between $£ 6$ and 13.5 million pounds (Smith and Whiting 2013). The fraudster supplied medicines that enhanced growth but which were not always legal in the country sold.

The question arises as to whether food fraud and wider food crime can be modeled as being enacted by lone individuals within a business setting, or whether such food crime is driven by a conspiracy of practice across a wider food supply chain or through organized criminal networks. A typology of food criminals must encompass both examples, as one model does not fit all thus the categorization of food crime and food criminals is further developed in this paper. Historic examples of food crime in the UK such as Operation Aberdeen and Operation Fox follow the conspiracy of practice model. Operation Fox involved passing condemned poultry back into the human food chain. As up to 1000 tonnes of rotten meat that should have been used for pet-food was redirected into the human food chain, the ten businessmen involved over eighteen premises were charged with conspiracy to defraud. Operation Aberdeen involved similar crimes of redirecting of waste meat. Six of the ten defendants were convicted and jailed for six years. In 
both the Operation Aberdeen and Operation Fox scenarios, although the numerous businessmen involved and convicted were not members of an organized crime group in the traditional sense, they were, nevertheless known to the police and the authorities for previous crimes of dishonesty or infractions of business legislation (Manning and Smith 2015). In both examples, the criminals operated from within recognized business structures as opposed to organized criminal structures. The crimes involved group led and conspiracy driven models committed by industry insiders. This facet of the crimes appears to have been overlooked at the time (See section 4 below). The crimes happened because unscrupulous food fraudsters saw and exploited an opportunity to make money from waste products because at the time there was little industry supervision or scrutiny. In all likelihood, the authorities lacked a pre-existing mental model (such as the one developed later in this paper) to help them appreciate that there was industry wide scope for such criminal practices. Nevertheless, Operations Aberdeen and Fox led to the setting up in the UK of the Food Fraud Data Base in 2006; The National Food Standards Agency (FSA) Task Force in 2007; and The Food Fraud Advisory Unit (FFAU) in 2009 and thus triggered the organization of UK authorities against food crime.

Food crime operates at many levels and can be a global, national or a localised issue. It spans the contexts of both urban and rural crime and criminality. Food crime can be committed in both short and long supply chains. The horsemeat scandal demonstrates the intricate nature and the complexity of long food supply chains. In that instance, the chain involved a food processor in France, its subsidiary in Luxembourg, a subcontractor in Cyprus, a meat trader in the Netherlands, abattoirs in Romania, and a number of food businesses in the UK, Ireland and across Europe selling the end products (NAO 2013). The report determines that since 2003 there have been a number of policy and market factors that might have increased the likelihood of food fraud, for example:

- Food fraud is harder to trace because of the increased complexity of the food supply chain; 
- The European Union (EU) has expanded, increasing the entry points for food from the rest of the world and there is the potential for variability in the effectiveness of controls;

- There are additional pressures on suppliers to cut supply chain costs, in the light of pressure on household budgets; and,

- Pressure on food availability worldwide has increased the cost of many ingredients and foods.

The European Parliamentary Research Service (EPRS 2014) in their briefing document "Fighting Fraud" highlight the reasons they believe led to the horsemeat incident namely the 2008 financial crisis and rising food prices driving a demand for cheap food, and more specifically cheap protein, the complexity of food supply chains, pressure on control services, the low risk of detection, the lack of focus on detecting food fraud and lastly the lack of a strong deterrent (penalties). Simultaneously, the 2008 financial crisis caused a number of additional horses to face slaughter because their owners could no longer pay for their keep, and the legal trade in horses was affected by this "over-supply". The scandal also demonstrates some of the challenges of maintaining product integrity and minimizing food crime if a food commodity changes hands frequently, on paper even if not in practice, over a range of national boundaries. There is also a local model of such substitution in a regional area, where again the "product" passes through several regulatory boundaries e.g. in the UK, at county level, it can change its identity e.g. horsemeat from the slaughter house can reappear as meat labeled as beef further down the supply chain. Manning and Smith (2015) identify that local and niche focused foods are at as much risk of food fraud as global chains where there is opportunity for individuals to substitute, falsify or mislabel.

A more sophisticated understanding of the organizational and operating practices of the food criminal in terms of their modus operandi and how individuals and groups develop criminal business models and networks will enable politicians, policy makers, investigators and academics to better understand the criminal individuals and the enterprises involved in food crime of which a part is food fraud. Therefore, the aim of this research is to: 
- Provide a synthesized literature review across seemingly disparate academic disciplines of food and agricultural policy, business theory and criminology; and

- Consider the modes of operation at work and develop a conceptual framework that considers the organizational dynamics, actors and drivers that interweave in criminal activity associated with animals and the meat trade with a view to enabling their mitigation.

\section{Categorizing food crime from an organizational perspective}

There is an increasingly blurred line between illegitimate commercial activities [criminologically associated with corporate or white-collar crime] and illegitimate economies and economic transitions [criminologically related to organized and professional crime] (See Croall 2009a: 166). Croall (2009b) categorized food crime as food poisoning, food adulteration and food fraud, misleading indications i.e. false claims such as low fat, misleading descriptions e.g. the use of the words "natural", "traditional", "pure", misleading pictures i.e. depictions on packaging that do not reflect the nature of the product inside, and the use of overlarge packaging suggesting that the food item inside is larger than the reality. Moreover, Spink and Moyer (2013) identified seven types of food fraud (as a sub-category of food crime) as previously described. We synthesize the literature sources to form a categorization of food crime (Table 1) building on the work of Croall (2009b).

Table 1 introduces the types of food fraud to be considered. Each type of food crime generates different potential levels of fiscal gains and the degree of gain is dependent on how well the 'crime' has been executed and if detection of the crime eventually occurs. Therefore food crime is undertaken by individuals and/ or groups with varying criminal and business modus operandi. Food criminals are clandestine, stealthy, and actively seek to avoid detection (Spink 2011). Spink et al. (2013) build on this theme and define criminal types and their attributes (See Table 2). Tables 1 and 2 should be consulted in conjunction with each other.

Take in Tables 1 and 2 
The varying motives and areas of activity associated with each criminal type means that diverse organizational and supply chain strategies are required to mitigate their actions by so-called "countermeasures". Valid countermeasures can include: the use of unique serial numbers at batch, product or lot level; traceability through measures such as Radio Frequency Identification Devices (RFID); and features on the packaging of individual items such as special inks, holograms, etc. on cases of product or on each pallet (Spink et al. 2010). Spink and Moyer (2011c) combine their work outlined in Tables 1 and 2 to develop a risk assessment matrix that can then drive the development of such countermeasures. Table 3 in this paper synthesizes the literature described in Tables 1 and 2.

\section{Take in Table 3}

Everstine et al. (2013) determine that EMA incidents reveal voids in quality assurance testing methodologies that are exploitable for intentional harm and/or economic gain. Indeed any gaps in traceability, quality assurance programs or interfaces between different certification schemes will be exploited where they occur by individuals for economic benefit. With specific emphasis on the meat supply chain, this could occur at the interface between farm and processing certification systems or the interaction between government and private business inspections such as in meat plants. Third party certification has been developed as a food industry reaction to the need for assurance of safe and legal food at all stages of the supply chain at farm, manufacturing and processing and at distribution level. However in the aftermath of the 2013 horsemeat scandal, a gap was identified at agent, or broker, level i.e. those organizations and individuals that only retain ownership of a food or food commodity at a "paper" level. They oversee the passage of food materials through the, often legitimate, physical supply chain by their actions at the commercial and organizational level. The British Retail Consortium (BRC) as a result of the 2013 scandal developed the BRC Global Standard for Agents and Brokers (BRC 2014) to augment their 
existing BRC Global Standards in an effort to mitigate the associated risk. Again there is a challenge as the certification audits are discrete and each with their own specific scope rather than an augmented, interactive process. Manning and Soon (2014) argue that it is important to consider whether third party certification of organizations against management system standards either guarantee increased compliance with statutory food standards product requirements or that such certification activities will address covert criminal behavior which by its nature involves the falsification of product, labeling and/or documentation at one point or several points in the supply chain. Indeed, criminal activity, is unlikely to occur during a timetabled third party certification audit promoting stealth as discovery of such practices would prohibit further financial gain (Manning and Soon 2014).

With specific emphasis on the meat supply chain, mechanisms can be developed to assess the likelihood of such crime and the potential for critical points where individuals have the opportunity to use/substitute/include different ingredients and materials (i.e. agricultural/veterinary inputs / processing stage) and use alternative packaging/labeling (i.e. at the packing or distribution stage). The complex nature of the interaction of predictive and reactive systems to mitigate food adulteration has been considered (See Manning and Soon 2014). Spink and Moyer (2013) argue that after a period of incorporating food fraud methodologies into risk assessment models, certification standards, supply chain assurance, and product verification, it may be equally difficult to remember a national or organizational food standards control program without there being a food fraud preventive system in place as it would be now a food safety system without the use of hazard analysis critical control point (HACCP) plans. However, using technical risk assessment approaches alone is flawed because by its nature crime is entrepreneurial and criminal activities evolve alongside changes in food law, testing regimes, supply chain specifications and standards. Considering food crime as simply a transactional process will limit the value of the risk categorization approach. Food crime involves a number of transformational elements that semi-quantitative risk assessment will not accommodate and a formal approach 
must consider and mitigate these as well. Risk rating matrices and other forms of semiquantitative risk ranking system are developed based on historic or existing knowledge and if used must continually evolve as knew knowledge becomes available thus being transactional. The horsemeat scandal demonstrates that emerging knowledge and behavior extends far beyond the recognized visible culture of the food supply chain. A transformational approach connects the failure of a leisure activity in one country with the opportunity for criminals in that country and others. In order for crime risk management approaches in the meat supply chain to be effective, policy makers and managers in organizations must interface with and understand basic criminological concepts and adopt an interdisciplinary approach to mitigate crime in the food industry (Everstine et al. 2013). This requires a combined transactional and translational approach.

\section{Transactional and transformational approaches to contextualizing the food criminal and their actions}

Transactional food crime management focuses on the policies, procedures and protocols, often called pre-requisites that drive formal management of food crime and illegality and minimize risk. Conversely, transformational food crime management engages all those who work for an organization, irrespective of job title, to consider their continued role in keeping the food that is produced legal and compliant. In reality, an effective food crime management culture will encompass both transactional and transformational management, tools and activity. Transactional food crime management ensures organizational systems, products and services comply with legislative requirements, drives resource allocation based on cost: benefit analysis, and determines appropriateness through prescribed compliance audits and other verification activities. People employed to deliver ongoing compliance with such standards can be managed by others to be task focused i.e. driven transactionally by job descriptions, task checklists and routine requirements, but this approach lacks an understanding of how human behavior and mindset shapes the degree of compliance with such standards and indeed the potential for human behavior to be a root cause of system failure. Transformational food crime management is about inspiring staff to feel food 
legality and compliance is important and to empower them to realize fully their specific role in ensuring compliance and that they are aware that there is always the potential for emerging or reemerging challenges that need to be effectively controlled, or if possible completely eliminated.

Schein's model of culture considered the basic underlying assumptions of the culture those that are "invisible and unconscious". Schein (1985) proposes that these assumptions are surrounded by the espoused values i.e. rules, standards and prohibitions. Such values by their nature are formal, transactional and define the values of the organization. Falkenberg and Herremans (1995) argue that within organizations it is difficult to separate the control of formal, and informal systems on behavior and furthermore that informal systems act to support and circumvent the formal systems that are in place. Each type of system, the formal and the informal (conscious and unconscious), has its own set of values and norms that may, or may not, be congruent. The challenge is when pressures within the informal system "encourage behaviors that are not aligned with the formally stated values and goals" (Falkenberg and Herremans 1995:134). It is important to consider that within an organization a range of sub-cultures may exist each with varying beliefs and values. In this context, Griffith (2014) described organizational culture as an umbrella term under which multiple cultures and multiple behaviors may exist. Although this work was in the area of food safety management it can be translated into considering food crime management.

\section{The behavioral approach to food crime}

Currently, prediction of the potential for an incident of food adulteration and/or other types of food crime rests upon the appropriate analysis of intelligence through the use of predictive tools and expert knowledge (Manning and Soon 2014). The information used to inform such risk assessment is often discrete, stored in a range of databases held by different regulators, private companies and other stakeholders or in knowledge repositories (including expert knowledge). Economic data that highlights market trends and supply chain vulnerabilities is usually completely 
disconnected from data on food incident and consumer complaint databases. This data is assessed often in the absence of a consideration of the motives and models of behavior of food criminals. Other business sectors such as the financial sector also have issues with identifying the potential for and mitigating fraud. This has led to a number of models being developed in this area. Gbegi and Adebisi (2013) determine the primary factors that influence fraud as pressure, opportunity and rationalization - the so-called fraud triangle:

- Pressure is differentiated into personal (individual e.g. financial or social pressure), employment (corporate pressure or management derived pressure) and external (business, stakeholder pressure to give a financial return, social and political environment and market (price) pressure);

- Opportunity to commit fraud is influenced by the level, or conversely the absence, of formal control systems in the business network or specific business situation, previously described in this paper as countermeasures and/or the potential for weaknesses or gaps in the business network. Weak security, the depth of knowledge of the ability to defraud, the ability to conceal the fraudulent act once committed and the access to the means to defraud all influence the degree of opportunity; and

- Rationalization being the ability of the individual to assess that their behavior is acceptable, even excusable to themselves and/or others.

Gbegi and Adebisi (2013) argue that understanding the opportunity for undertaking fraud behavior in a given process allows forensic accountants to identify the types of fraud an individual can commit and this type of approach could be extended to food fraud and wider food crime analysis, thus reducing the potential for such opportunity to arise. Further, Gbegi and Adebisi determine that the risk of fraud increases when the controls put in place do not operate as intended by management i.e. if management monitor the controls in place and their adequacy on a regular basis then this will reduce the likelihood of fraud. This element translates too when considering the processes within the food supply chain where hot-spot analysis has been used historically to 
determine weaknesses and vulnerabilities in the food supply chain and how controls can be put in place (pre-requisites) to prevent incidents occurring. One must also consider that the formal and informal culture and sub-cultures that operates within the food business is of value too in preventing or condoning illicit behavior.

Wolf and Hermanson (2004) posited the fraud diamond model - breaking the three elements previously described into four and adding the dimensions of capability to opportunity, rationalization and incentive or pressure. Gbegi and Adebisi (2013) also drafted their own diamond fraud model with the factors being capability, opportunity, motivation, and personal integrity. These models inform the basis of the conceptual model developed in this study. UK food industry insiders we interviewed identified two main basic types of crime/criminal in the food supply chain (Smith and Laing 2013):

1. Parasitical type crime, generally committed as theft by organized crime groups who target livestock with the intention of passing the resultant meat, illegally into the food chain e.g. sheep rustling, poaching of wild animals or illegal harvesting of shellfish; or

2. Insider type crime, where food business operators become involved in the misrepresentation, mislabeling or adulteration of product by adding cheaper and often potentially dangerous alternatives. In the case of meat (Operations Aberdeen and Fox) the alternative ingredient/material may have been condemned or previously classified as unfit for human consumption. Moreover, traditional organized crime is undertaken by crime groups or Mafias and is usually known to police and the authorities. The lone businessman is an individual with criminal inclinations and propensities whom is either targeted by organized crime groups or who align themselves to them.

The category of criminal committing the fraud is an important consideration because each type of criminal has a different modus operandi. Canter (2000) argues that whilst the individual actions of an offender may not all be identical from one crime to the next the themes that characterize those crimes may often be reasonably consistent i.e. that offenders operate within a limited conceptual space that can be defined as has also suggested by Spink et al. (2013). Canter 
further differentiates between different types of offenders using the criteria of criminal versus non-criminal; class of crime i.e. whether the activity is against property or an individual; type of crime; the pattern of criminal action; the modus operandi and the criminal signature. It should be noted that types of criminal are not mutually inclusive/exclusive and that to sell their stolen or appropriated goods, organized crime groups must form alliances with single, or multiple food business operators in the food crime network. Criminal networks are characterized by diversity in composition, density of connections, size, structure, shape, underlying bonding mechanisms, degree of sophistication, and scope of activities (Williams 2001). Further, Williams states that criminal networks feature a considerable division of labor among members and that a series of critical roles can be identified (Table 4) and argues that the capacity to cross national borders creates several advantages for criminal networks because it enables them to supply markets where the profit margins are largest, whilst operating from and in countries where risks are the least.

\section{Take in Table 4}

Table 4 sets out the roles adopted within criminal networks. In some networks, the tasks delegated to individuals will be implicit and intuitive; while in others, they are explicit and formal (Williams 2001). A criminal eco-system develops around these practices and this brings routine activities theory into play (Felson 2006). This theory suggests that criminals are vulnerable in their everyday settings because they develop routines and common practices that make them predictable and thus interdictable. Adopting Felson's approach of identifying events, sequences and settings is helpful in developing food crime risk assessment (FCRA) models. Moreover, when dealing with such crime there is a tendency to be transactional i.e. to concentrate on the evidential and the criminal (and thus modus operandi) as opposed to the wider holistic picture of how the actors fit into the entrepreneurial crime business models and supply chain networks as described by Williams.

In order to interdict the organized crime groups and criminal businesses involved in food crime (and criminal entrepreneurship in general) it is necessary to develop a sophisticated 
understanding of how the criminals operate and how the businesses are organized. The tested model of Osterwalder and Pigneur (2010) provides a useful tool that could be adapted to map the criminal business methods used by criminal organizations involved in the supply and exploitation of food particularly in relation to its nexus at the cross section of criminology and the economy. The 'Business Canvass Model' consists of nine basic building blocks: customer segments, value propositions, channels, customer relationships, revenue streams, key resources, key activities, key partnerships, and cost structure. These building blocks can be adapted and developed to incorporate other elements of business practice including the informal and the criminal. Food crime involves a complex framework of organized crime groups and criminal businesses. It may also include unwittingly involved law abiding organizations whilst criminal businesses may use the cover of legal business activity (Williams 2001). Mapping the indicators, contexts, practices and outcomes identified onto the canvass helps in the modeling process (Scott et al. 2012). In addition, building upon this business model approach, the theoretical model developed by Smith (2009) proves helpful in investigating and documenting different criminal and business practices and behavioural characteristics reported upon in previous studies. From this process of review several different patterns based on modus operandi and modus vivendi emerge that could inform the development of the protean business models that assist with the development of an organizational typology of criminals. These models can be used to explore the possibilities for interdicting and disrupting the criminal activities within as in this example, the meat supply, and also the wider food supply chain (Smith 2004; Wilkinson et al. 2010; Smith and McElwee 2013). Furthermore, Canter (2000) also considers the influence of the relationship between the offender/perpetrator and the victim. If the victim is seen as an object only by the perpetrator then there will be few emotional elements to the food crime. However the perpetrator may relate to the victims as a vehicle e.g. a crime directed at children through targeted food (milk powder, baby food) may be influenced by emotion e.g. ideology or anger at society as a whole. Thus the crime is directed at a vulnerable group in that population or the crime could be personal against a known 
group or individual or as a result of an event that occurred in the perpetrator's own personal life. This approach also has value when translated to food crime. PAS 96 (2014) highlights a series of criteria that can be used in the quantification of vulnerability to food crime and these have been drawn together with the other literature discussed in this paper within the construct of the "fraud diamond" (Table 5).

\section{Take in Table 5}

Spink et al. $(2013 ; 2014)$ consider the categorization of offender types in more detail in an effort to determine appropriate countermeasures and they argue that an offender can be identified either as a result of their profile (offender-based) or their activity (offense-based). In determining the potential for occurrence according to offender type some categories such as recreational or occasional criminal types may be of a low risk to the organization if appropriate countermeasures are implemented as opportunities to perpetrate the crime(s) can be minimized. The type of business, the ability to deliver an economic gain or the ease of committing food crime may mean that some products are not at risk of being vehicles for ideological, occupational or professional criminals. However if an individual can operate unnoticed in an organization or operates in collaboration with the organization there is the opportunity for occupational crime especially where such activity is ignored or encouraged by management (Table 2). Spink et al. (2013) argue that the scale of opportunity is also a function of the level of organization of the criminals and therefore the degree of formalization of the criminal network or association plays a part too. Spink et al. (2014) considered this factor in the development of their product-counterfeiting incident cluster tool. In the research they categorize the types of offender organizations and this has been adapted in this study.

Criminal networks are an important complement to traditional markets and supply chains (Williams 2001). This makes them efficient, reduces transaction costs, and provides increased business opportunities for both buyers and sellers especially in a time of low cost trans-global 
communication. Networks have multiple characteristics and can vary in size, location (local or global), shape (cohesive or diffuse), membership, cohesion (goal-focused or disparate), and purpose (Williams 2001). However, compartmentalization of information and knowledge as well as operational management gives greater assurance of survival of a part of the criminal network, and its business activities, in the event of whistle blowing, or infiltration by regulatory or law enforcement agencies. Furthermore, Williams argues that governments, and in this context agencies such as the FSA and the European Food Standards Authority (EFSA), still operate along hierarchical lines and are further hindered by bureaucratic rivalry and competition, interagency antipathies, and a hesitance to share information, align databases and coordinate operations. This may be a manifestation of investigational carefulness. This naturally makes them less agile than the criminal networks they are seeking to address.

Our conceptual framework (Figure 1) emerged from the synthesis of the interdisciplinary literature reviewed and considers the actors and drivers involved in food associated criminal activity and demonstrates that FCRA is only one element of a food crime management (FCM) program.

\section{Take in Figure 1}

Consideration needs to be given to a number of factors that are often industry specific and will vary from year to year especially as they influence the dynamics between supply and demand. A FCM program will contain transactional elements such as semi-quantitative risk assessment and priority setting. However because so much of the culture of food crime sits at the visible/invisible interface and the legitimate/illegitimate interface developing visible countermeasures is not enough. A transformational approach is required that might include criminal and victim profiling and analysis of behavioral factors as well. This holistic approach is essential to tackle the challenges that present themselves to the food industry and at policy level too. 


\section{Developing a conceptual framework for typing criminals and their activity in the meat supply chain}

The various literatures reviewed in this research have been synthesized in order to categorize the types of food supply chain offender organization, network, or sub element of a network and the types of criminal offense that may occur. Using the criteria in Table 2, ideological crime needs to be considered as a separate type of food crime because it is very context focused and the motive and rationalization for terrorist activities is different to wider food crime. The work of Spink et al. (2013); Spink et al. (2014) and Williams (2001) highlight particular elements of, or roles within, crime organizations and networks. When this work is considered within the context of food crime it highlights the potential vulnerabilities for organizations seeking to mitigate food crime (Table 6) and potential supply chain countermeasures that could be of value. To this we add a further nuanced typological model based on the occupation and motivation of the food criminal with specific emphasis on the meat trade to create a more sophisticated tool (Table 7).

\section{Take in Tables 6 and Table 7}

The modus operandi and vivendi of the different groups are described. Although emphasis is placed on the meat trade the examples used translate to other commodity and high value food chains. The first category identified consists of 'Industry Insiders'. These are a diverse group that includes rogue and criminal farmers; rogue entrepreneurs and small businessmen; rogue butchers and meat traders; and 'Specialist Workers' each of which have differing modus operandi and vivendi. The second category identified consists of 'Industry Outsiders'. These include criminal mafias and cartels; organized crime groups; disorganized criminals and criminal labour. In order to undertake food crime risk assessment activities where the degree of food crime risk is actually determined on a case by case basis, organizations need to consider the type of criminal activity and also the likelihood for this activity to be associated with their materials and products. Once the potential crimes have been identified the organization needs to consider the actual 
countermeasures and controls that are currently in place and their efficacy, or that should be implemented whichever is appropriate to the situation in order to determine the actual magnitude of risk once mitigation has been undertaken. This approach is worthy of further study to consider how a countermeasures framework could be designed and effectively implemented.

\section{Discussion}

The synthesis of literature from seemingly disparate academic disciplines of food and agricultural policy, business theory and criminology and to characterize the modes of operation at work in such networks has allowed for the development of occupational and motivational typological tools that can be used in assessing the intricate nature of food crime in the meat trade. This approach can be applied to other sectors. The European Horsemeat Scandal of 2013 highlighted the increasing organization and sophistication of the contemporary food criminal. Our conceptual framework considers the actors and drivers involved in criminal activity using the meat supply chain as an example. FCM procedures require not only that a formal risk assessment has been undertaken but also that countermeasures have been validated and are verified on a routine basis to ensure their continued appropriateness and effectiveness. This research has provided more sophisticated and nuanced understanding of the organizational ability of the food criminal, in terms of their modus operandi, and how individuals and groups develop criminal business models and networks in the meat supply chain. This research demonstrates the challenge of mitigating the activities of those individuals, criminal and commercial organizations exploiting the existing vulnerabilities at the interface between legitimate and illegitimate business activity. 


\section{References}

Ballin, N. Z. (2010), Authentication of meat and meat products. Meat Science, 86: 577-587.

BRC (2014), British Retail Consortium Global Standard for Agents and Brokers, Food and Packaging Materials, Issue 1. January 2014. ISBN 9780117082373 TSO London.

Budiansky, S. (1999). The covenant of the wild: why animals chose domestication. Yale, Yale University Press.

Canter, D.V. (2000), Offender profiling and criminal differentiation, Legal and Criminal Psychology, 5(1): 23-46. ISSN 1355-3259

Croall, H., (2009a), Who is the white-collar criminal? British Journal of Criminology, 29(2): 157-174.

Croall, H. (2009b). White collar crime, consumers and victimization, Crime, Law and Social Change, 51: 127-146

Desmond, J. (2010). A summons to the consuming animal. Business Ethics : a European Review 19(3).

EPRS (2014), European Parliamentary Research Service, briefing document Fighting Fraud, 130679REV1 Issued 16/01/2014

Everstine, K. Spink, J. and Kennedy, S. (2013), Economically motivated adulteration (EMA) of food: common characteristics of EMA incidents. Journal of Food Protection, 4: 560-735.

Falkenberg, L., and Herremans, I. (1995), Ethical Behaviours in Organizations: Directed by the formal or informal systems, Journal of Business Ethics, 14: 133-143

Felson, M. (2006), The ecosystem for organized crime, Heuni paper No 26.

FSA (nd ) Food Standards Agency Website Available at:

https://www.food.gov.uk/enforcement/enforcework/foodfraud [Date accessed 04.07.14]

Gallagher, M. and Thomas, I. (2010), Food fraud: The deliberate adulteration and misdescription of foodstuffs, European Food and Feed Law Review, 6: 347-353.

Gbegi, D.O. and Adebisi, J.F. (2013), The new fraud diamond model- how can it help forensic accountants in fraud investigation in Nigeria? European Journal of Accounting Auditing and Finance Research 1(4):129-138, December 2013 Published by European Centre for Research Training and Development UK (www.eajournals.org)

Griffith, C. (2014), Developing and Maintaining a Positive Food Safety Culture. $1^{\text {st }}$ Edition. Highfield Publications.

Grundy, H.H. Kelly, S.D. Charlton, A.J. Donarski, J.A. Hird, S.J. and Collins, M.J. (2012). Food Authenticity and Food Fraud Research: Achievements and Emerging Issues, Journal of the Association of Public Analysts (Online) 40: 65-68 
Jones, C., M. Parker and R. Bos (2005) For Business Ethics: A Critical Approach, Routledge, London

Manning, L., and Smith R. (2015), Providing authentic(ated) food: An opportunity driven framework for small food companies to engage consumers and guarantee the integrity of the food supply chain, International Journal of Entrepreneurship and Innovation, 16(2) 97 - 110

Manning, L and Soon, J.M, (2014), Developing systems to control food adulteration, Food Policy, 49(1): 23-32

Manning L. Baines R.N. and Chadd S.A. (2005), Deliberate contamination of the food supply chain, British Food Journal, 107(4): 225-245.

Mueller, T. (2007), The New Yorker, August 13, available at: wwww.newyorker.com/reporting/207/08/13/070813fa_fact_mueller.

Nakyinsige, K., Che Man, Y. and Sazili, A. Q. (2012), Halal authenticity issues in meat and meat products. Meat Science 91(3): 207-214.

National Audit Office (2013). Food safety and authenticity in the processed meat supply chain. The Food Standards Agency, Department for Environment, Food \& Rural Affairs, Department of Health. Report by the Comptroller and Auditor General Ordered by the House of Commons to be printed on 9 October 2013.

National Audit Office (2002), The 2001 Outbreak of Foot and Mouth Disease. Report by the Comptroller and Auditor General HC 939, Session 2001-2002: 21 June 2002. Ordered by the House of Commons to be printed on 18 June 2002

Nerlich, B. Hamilton, C.A and Rowe, V. (2004) Conceptualising Food and Mouth Disease: The Socio-Cultural Role of Metaphors, Frames and Narratives. Available at: metaphorik.de: http://www.metaphorik.de/02/nerlich.htm [Accessed 09.11.14]

Osterwalder, A. and Pingeur, Y. (2010), Business Model Generation, London: John Wiley \& Sons Inc.

Publicly Available Specification (PAS) 96:2014 Defending Food and Drink. BSI London.

Schein, E. H. (1985), Organizational culture and leadership. San Francisco, CA: Jossey-Bass.

Scott, S., Craig, G., and Geddes, A., (2012), Experiences of Forced Labour in the UK Food Industry, Joseph Rowntree Foundation.

Shears, P. (2010), Food Fraud - a current issue but an old problem, British Food Journal, 112 (2): 198-213.

Smith, R., and Laing, A., (2013). Listening to alternative perspectives on rural crime and criminality: a report on the pilot study. SIPR Research Summary 15. 
Smith, R. and McElwee, G. (2013), Confronting Social Constructions of Rural Criminality: A Case Story on 'Illegal Pluriactivity' in the Farming Community, Sociologia Ruralis, 53(1): 112134.

Smith, R. and Whiting, M. (2013), Documenting and Investigating the entrepreneurial trade in illegal veterinary medicines in the United Kingdom and Ireland, Handbook of Veterinary Business and Enterprise, Elsevier

Smith, R. (2009). Understanding Entrepreneurial Behaviour in Organised Criminals, Journal of Enterprising Communities: People and Places in the Global Economy, 3(3): 256 -268

Smith, R. (2004), Rural Rogues: A Case Story on the Smokies Trade, The International Journal of Entrepreneurial Behaviour and Research, 10(4): 277-294.

Spink, J., Moyer, D.C, Park, H. and Heinonen, J.A (2014), Development of a productcounterfeiting incident cluster tool, Crime Science, 3:3

Spink, J., Moyer, D.C, Park, H. and Heinonen, J.A (2013), Defining the types of counterfeiters, counterfeiting and offender organizations, Crime Science, 2:8

Spink, J. and Moyer, DC. (2013), Understanding and Combating Food Fraud, Food Technology, 67(1): 30-35.

Spink, J. and Moyer, D.C. (2011a), Defining the Public Health Threat of Food Fraud'. Journal of Food Science, 76(9): 157-162.

Spink, J. and Moyer, D.C. (2011b), Backgrounder: Defining the Public Health Threat of Food Fraud, in Research Grants. National Center for Food.

Spink, J. and Moyer, D.C. (2011c), Types of Counterfeiters and Counterfeiting. Paper presented at the School of Criminal Justice. $75^{\text {th }}$ Anniversary Symposium.

Spink, J. (2011), The Challenge of Intellectual Property Enforcement for Agriculture Technology Transfers, Additives, Raw Materials, and Finished Goods against Product Fraud and Counterfeiters, Journal of Intellectual Property Rights, 16(2):183-193.

Spink, J., Helferich, O.K., and Griggs, J.E. (2010). Combating the Impact of Product Counterfeiting. Distribution Business Management Journal 10(1), 6.

Wilkinson, M. Craig, G. and Gaus, A. (2010), Forced labour in the UK and the Gangmasters Licensing Authority, Contemporary Slavery Research Centre, Hull.

Williams, N. M., (2008) 'Affected ignorance and animal suffering : why our failure to debate factory farming puts us at moral risk '. Journal of Agricultural and Environmental Ethics (2008), No 21, pp. 371-384.

Williams, P. (2001), Transnational Criminal Networks in J. Arquilla and D. Ronfeldt (eds), Networks and Netwars: The Future of Terror, Crime and Militancy. Santa Monica: Rand Corporation, 61-97. 
Wolf, D.T. and Hermanson, D.R. (2004). The Fraud Diamond: Considering the Four Elements of Fraud: The Certified Public Accountants (CPA) Journal.

Table 1. Types of food crime (Adapted from Spink and Moyer, $2013^{1}$ and Croall $2009 b^{2}$ )

\begin{tabular}{|c|c|c|}
\hline Type $^{1}$ & Definition ${ }^{1}$ & Definition $^{2}$ \\
\hline Adulteration & A component of the finished product is fraudulent. & Product adulteration. \\
\hline Counterfeit & $\begin{array}{l}\text { All aspects of the fraudulent product and packaging } \\
\text { are fully replicated. }\end{array}$ & \\
\hline Diversion & $\begin{array}{l}\text { The sale or distribution of legitimate products outside } \\
\text { of intended markets. }\end{array}$ & \\
\hline Over-run & $\begin{array}{l}\text { Legitimate product is made in excess of production } \\
\text { agreements. }\end{array}$ & \\
\hline Simulation & $\begin{array}{l}\text { Illegitimate product is designed to look like but does } \\
\text { not exactly copy the legitimate product. }\end{array}$ & \\
\hline Tampering & $\begin{array}{l}\text { Legitimate product and packaging are used in a } \\
\text { fraudulent way. }\end{array}$ & \\
\hline Theft & $\begin{array}{l}\text { Legitimate product is stolen and passed off as } \\
\text { legitimately procured. }\end{array}$ & \\
\hline $\begin{array}{l}\text { Malicious poisoning, } \\
\text { bioterrorism or } \\
\text { sabotage }\end{array}$ & $\begin{array}{l}\text { Any of the above can lead to harm to the consumer } \\
\text { depending on the nature of the crime. }\end{array}$ & Food poisoning. \\
\hline $\begin{array}{l}\text { Misleading } \\
\text { indications (words/ } \\
\text { pictures) }\end{array}$ & & $\begin{array}{l}\text { Use of words such as "natural", } \\
\text { "traditional". Use of pictures e.g. } \\
\text { depictions on packaging that do not reflect } \\
\text { the nature of the product inside or the } \\
\text { methods of production. }\end{array}$ \\
\hline Packaging size $^{2}$ & & Use of overlarge packaging. \\
\hline
\end{tabular}

Table 2. Criminal types and attributes (Adapted from Spink et al. 2013)

\begin{tabular}{|c|c|c|}
\hline $\begin{array}{c}\text { Types of } \\
\text { Criminals } \\
\end{array}$ & Definition & $\begin{array}{c}\text { Magnitude of risk } \\
\text { (Likelihood/Severity) }\end{array}$ \\
\hline Ideological & $\begin{array}{l}\text { Domestic or international terrorist who } \\
\text { commits the criminal act to make an } \\
\text { ideological statement or to economically } \\
\text { harm an entity, or to create panic and fear } \\
\text { in the target population. }\end{array}$ & $\begin{array}{l}\text { Magnitude will depend on the nature of the product, } \\
\text { organization, supply chain and/or the population targeted. }\end{array}$ \\
\hline Occasional & Infrequent, opportunistic individual. & $\begin{array}{l}\text { Low risk potentially mitigated by implementing } \\
\text { appropriate countermeasures. }\end{array}$ \\
\hline Occupational & $\begin{array}{l}\text { Crime occurs at the place of employment, } \\
\text { either as an individual acting alone or in } \\
\text { collaboration with the modus operandi of } \\
\text { the organization. }\end{array}$ & $\begin{array}{l}\text { Magnitude of risk increases especially if individual can } \\
\text { operate unnoticed in an organization or operates in } \\
\text { collaboration with the organization. Potentially a degree of } \\
\text { mitigation by implementing appropriate countermeasures } \\
\text { unless the activity is deliberately ignored or encouraged by } \\
\text { management. }\end{array}$ \\
\hline Professional & $\begin{array}{l}\text { Criminal activity fully finances their } \\
\text { lifestyle. }\end{array}$ & $\begin{array}{l}\text { Magnitude of risk increases and will depend on the nature } \\
\text { of the product, organization, supply chain and/or the } \\
\text { population targeted. }\end{array}$ \\
\hline Recreational & $\begin{array}{l}\text { Undertakes crime for entertainment or } \\
\text { amusement. }\end{array}$ & $\begin{array}{l}\text { Low risk potentially mitigated by implementing } \\
\text { appropriate countermeasures. }\end{array}$ \\
\hline
\end{tabular}


Table 3. Crime types matrix according to criminal and type of offense (Adapted from Spink et al. 2014; Spink and Moyer 2011c; Croall 2009b)

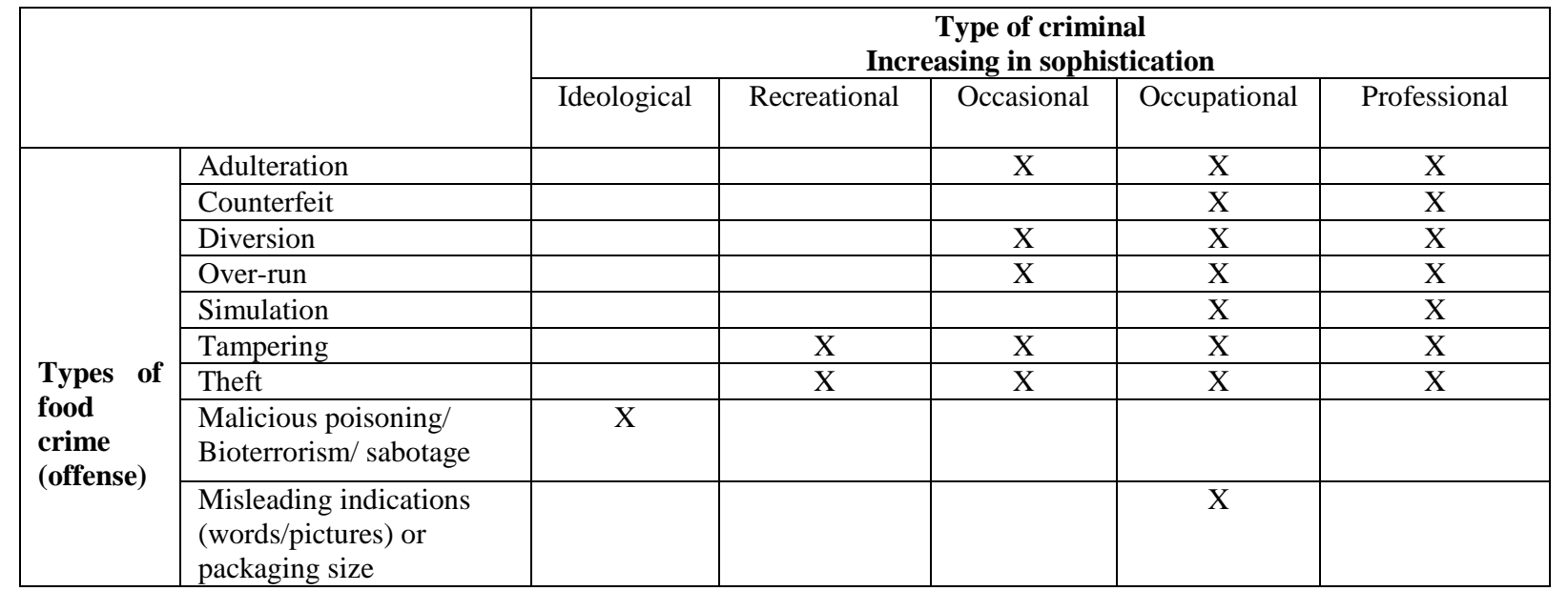

$\mathrm{X}$ - identifies where this crime can occur

\section{Table 4. Roles in criminal networks (Adapted from Williams 2001)}

\begin{tabular}{|l|l|}
\hline \multicolumn{1}{|c|}{ Role } & \multicolumn{1}{c|}{ Description } \\
\hline Organizers & $\begin{array}{l}\text { Core individuals and groups that provide the steering mechanism for the network. These organizers } \\
\text { generally determine the scale and scope of activities and guidance and provide the impetus for their } \\
\text { execution. }\end{array}$ \\
\hline Insulators & $\begin{array}{l}\text { Individuals or groups whose role is essentially to insulate the core from the danger posed by infiltration } \\
\text { and compromise. They transmit directives and guidance from the core to the periphery of the network } \\
\text { ensuring that communication flows from the periphery do not compromise the individuals and groups in } \\
\text { the core. }\end{array}$ \\
\hline Communicators & $\begin{array}{l}\text { Individuals who ensure that communication flows effectively from one actor to another across the } \\
\text { network. They transmit directives from the core group and provide feedback. Some individuals may be } \\
\text { insulators and communicators. }\end{array}$ \\
\hline Guardians & $\begin{array}{l}\text { Enforcers concerned with maintaining the security of the network, implementing measures to minimize } \\
\text { vulnerability to external attack or infiltration and damage to the network. }\end{array}$ \\
\hline Extenders & $\begin{array}{l}\text { Extend the network by recruiting new members, by negotiating with other networks regarding } \\
\text { collaboration, or encouraging defectors from the world of business, government, and law enforcement. }\end{array}$ \\
\hline Specialists & $\begin{array}{l}\text { Depending on the nature of the food fraud, specialist skills may be required e.g. chemists, technologists, } \\
\text { etc. }\end{array}$ \\
\hline
\end{tabular}


Table 5: Criteria for determining risk of food crime (Adapted from Croall 2009b; EPRS 2014; Everstine et al. 2013; Gbegi and Adebisi 2013; NAO 2013; Osterwalder and Pigneur 2010; PAS 96 2014; Spink et al. 2014; Spink and Moyer 2011c; Williams 2001; Wolf and

\section{Hermanson 2004)}

\begin{tabular}{|c|c|c|c|c|}
\hline $\begin{array}{c}\text { Generic threats } \\
\text { to food and } \\
\text { drink }\end{array}$ & Motive/Incentive/ Pressure & Rationalization & Opportunity & Capability \\
\hline $\begin{array}{l}\text { Malicious } \\
\text { contamination } \\
\text { with toxic } \\
\text { materials causing } \\
\text { ill-health and even } \\
\text { death. } \\
\text { Sabotage of the } \\
\text { supply chain } \\
\text { leading to food } \\
\text { shortage. } \\
\text { Misuse of food } \\
\text { and drink } \\
\text { materials for } \\
\text { terrorist or } \\
\text { criminal purposes. } \\
\text { Other food crime } \\
\text { (as identified } \\
\text { Table 3). }\end{array}$ & $\begin{array}{l}\text { Type of perpetrator e.g. people with no connection to } \\
\text { the organization; those with a contractual relationship } \\
\text { such as suppliers and contractors; those who work for } \\
\text { the organization. } \\
\text { Product characteristics } \\
\text { e.g. product has a particular religious, ethical or moral } \\
\text { significance. } \\
\text { Impact i.e. foods that are widely disseminated or } \\
\text { distributed in the population will increase impact or the } \\
\text { target is an ingredient that is used in a multiplicity of } \\
\text { products e.g. Sudan I incident. } \\
\text { Organizational profile i.e. } \\
\text { profile of the organization, brands, or individuals within } \\
\text { the organization make them more liable to threat; } \\
\text { alienated or disaffected staff. } \\
\text { Personal pressure/integrity e.g. financial gain or social } \\
\text { pressure. } \\
\text { Employment pressure e.g. corporate or management } \\
\text { derived e.g. low staff morale or performance demands } \\
\text { that are difficult to deliver using existing norms and } \\
\text { behaviors. } \\
\text { External or environmental pressure e.g. business, } \\
\text { stakeholder demands, financial, social, political or } \\
\text { market pressure. }\end{array}$ & $\begin{array}{l}\text { Low risk of detection. } \\
\text { Lack of anti-food crime countermeasures. } \\
\text { Limited consequences to individual e.g. lack } \\
\text { of strong deterrent (legal or market). } \\
\text { Acceptability of behavior i.e. personal or } \\
\text { group acceptance of criminal or non-criminal } \\
\text { behavior. } \\
\text { Role in criminal network i.e. rationalization } \\
\text { process will be different for different roles } \\
\text { organizers, guardians, specialists etc. (Table } \\
\text { 5). } \\
\text { Realization i.e. attacker wants to see an } \\
\text { immediate and acute financial or health impact } \\
\text { (terrorist group) or conversely the substitution } \\
\text { has a chronic impact e.g. dioxin so it can go } \\
\text { unnoticed for decades and/or the incidence } \\
\text { may be so sporadic in the population that it is } \\
\text { unlikely to be linked to a single source. } \\
\text { Alternatively the perpetrator has no concern } \\
\text { for the impact of the crime on individuals or } \\
\text { organizations, or indeed there is no health } \\
\text { impact. } \\
\text { Financial gain overcoming considerations of } \\
\text { personal integrity. }\end{array}$ & $\begin{array}{l}\text { Low risk of detection i.e. likelihood of routine } \\
\text { QC/QA procedures to detect criminal activity. } \\
\text { Lack of anti-food crime countermeasures } \\
\text { e.g. lack of unique identity at product, lot and } \\
\text { batch level; weak level of formalization of } \\
\text { business, supply chain and national controls; } \\
\text { physical, electronic and personnel security } \\
\text { procedures. } \\
\text { Vulnerability e.g. variability in border } \\
\text { controls, gaps, hotspots or vulnerabilities in the } \\
\text { supply chain, expanding global markets and } \\
\text { pressures on services; multiple boundary } \\
\text { interfaces in a complex supply chain; } \\
\text { vulnerable points at which criminal activity } \\
\text { might take place. } \\
\text { Location: premises located in a politically or } \\
\text { socially sensitive area; premises or services } \\
\text { accessible to potential perpetrators; product } \\
\text { contain ingredients or other material sourced } \\
\text { from sensitive or insecure areas. } \\
\text { Environment e.g. hazardous materials or } \\
\text { potential agents are stored on the production } \\
\text { site; inadequately sealed transport and limited } \\
\text { tamper evident containment; challenges with } \\
\text { zoonotic animal diseases in areas where there } \\
\text { are poor controls or knowledge. }\end{array}$ & $\begin{array}{l}\text { Capacity i.e. } \\
\text { sufficient } \\
\text { resources, } \\
\text { partnerships, } \\
\text { knowledge. } \\
\text { Channels } \\
\text { exist to } \\
\text { perpetrate the } \\
\text { crime. }\end{array}$ \\
\hline
\end{tabular}


Table 6: Criminal elements and enterprises (Adapted from Spink et al. 2013; Spink et al. 2014; Williams 2001)

\begin{tabular}{|c|c|c|c|}
\hline $\begin{array}{l}\text { Types of } \\
\text { enterprise }\end{array}$ & Definition of enterprises & $\begin{array}{l}\text { Vulnerable roles within the network (see } \\
\text { Table 4) }\end{array}$ & $\begin{array}{l}\text { Vulnerable activities and potential mitigation by food supply chain } \\
\text { countermeasures }\end{array}$ \\
\hline Network Core & $\begin{array}{l}\text { Characterized by dense, often family or clan, connections between } \\
\text { individuals acting as a directed network, providing the steering } \\
\text { mechanism for the network. }\end{array}$ & $\begin{array}{l}\text { Limited vulnerability for organizers if } \\
\text { insulators and guardians are effective. }\end{array}$ & $\begin{array}{l}\text { Interception and infiltration of information flow from insulators to } \\
\text { organizers. }\end{array}$ \\
\hline $\begin{array}{l}\text { Network } \\
\text { Peripheries }\end{array}$ & $\begin{array}{l}\text { Individuals and organizations with weaker connections to the } \\
\text { network core. The more extensive the periphery operations the } \\
\text { more extensive and diverse the network can be socially, } \\
\text { operationally in terms of their reach. } \\
\text { The periphery provides the intelligence that suggests potential } \\
\text { vulnerabilities and its interaction with the core driving } \\
\text { entrepreneurial activity in terms of adaptability and reinvention of } \\
\text { the organizational model. }\end{array}$ & $\begin{array}{l}\text { Communicators, extenders and specialists } \\
\text { form vulnerable roles in the network. }\end{array}$ & $\begin{array}{l}\text { Communications between roles and legitimate and illegitimate } \\
\text { organizations. } \\
\text { Control levels of authority and communication channels within the } \\
\text { legitimate organization/supply chain. Limit knowledge of product, its } \\
\text { characteristics, formulation and packaging to specific individuals internal } \\
\text { and external. Monitor internal/external factors that increase } \\
\text { organizational vulnerability to crime - staff turnover, supply trends, etc. }\end{array}$ \\
\hline $\begin{array}{l}\text { Critical } \\
\text { Network } \\
\text { Node }\end{array}$ & $\begin{array}{l}\text { An individual or organization that functions within a criminal } \\
\text { network who cannot be easily replaced because they possess } \\
\text { information, knowledge, skills and resources essential to the } \\
\text { criminal network. Removal seriously affects the functioning of the } \\
\text { network e.g. a laboratory making the substitute material that is } \\
\text { being used in an incidence of food fraud. }\end{array}$ & $\begin{array}{l}\text { Specialists - individuals and organizations } \\
\text { with food supply chain knowledge and } \\
\text { technical ability to substitute, counterfeit } \\
\text { etc. } \\
\text { Laboratories, alternative manufacturers, } \\
\text { packaging companies counterfeiting } \\
\text { packaging, food technologists }\end{array}$ & $\begin{array}{l}\text { Build into the process manufacturing elements that cannot easily be } \\
\text { replicated. Embed those facilities into secure elements of the site - } \\
\text { keypad entry, designated personnel, etc. } \\
\text { Secure product knowledge within the organization, introduce markers } \\
\text { into the food product so that counterfeiting, substitution is more easily } \\
\text { recognized. }\end{array}$ \\
\hline $\begin{array}{l}\text { Directed } \\
\text { Criminal } \\
\text { Network }\end{array}$ & $\begin{array}{l}\text { An association of individual criminals, criminal enterprises and } \\
\text { groups formed for a specific purpose e.g. to substitute horsemeat } \\
\text { for beef at a specific stage in the supply chain before relabeling and } \\
\text { passing it on to unsuspecting individuals/organizations. Directed } \\
\text { criminal networks can form wider translational criminal networks. }\end{array}$ & $\begin{array}{l}\text { Organizers, Insulators, } \\
\text { Communicators, Guardians, } \\
\text { Extenders, Specialists }\end{array}$ & \multirow{3}{*}{$\begin{array}{l}\text { Supplier assurance protocols. Develop countermeasures to identify the } \\
\text { assurance measures necessary to mitigate. Develop supply chain } \\
\text { partnerships e.g. increased integration and embedding of chain. } \\
\text { Monitor changes in the economics of the supply chain with emphasis on } \\
\text { when food crime would prove most lucrative. }\end{array}$} \\
\hline $\begin{array}{l}\text { Transactional } \\
\text { Criminal } \\
\text { Network }\end{array}$ & $\begin{array}{l}\text { An association of individual criminals, criminal enterprises and } \\
\text { groups that form as a result of a desire to improve efficiency and } \\
\text { reduce transactional costs. e.g. a network that comes together with } \\
\text { the sole purpose of reducing cost in a supply chain and where } \\
\text { "brokers" play a pivotal role at several stages in the supply chain. }\end{array}$ & Brokers prove to be the vulnerability. & \\
\hline $\begin{array}{l}\text { Multi- } \\
\text { collaboration } \\
\text { Networks }\end{array}$ & $\begin{array}{l}\text { An association or strategic alliance between different criminal } \\
\text { networks or between them and a terrorist organization for a } \\
\text { common good. The pooling of resources aids the overall } \\
\text { achievement of mutual and differentiated goals. }\end{array}$ & $\begin{array}{l}\text { Organizers, Insulators, } \\
\text { Communicators, Guardians, } \\
\text { Extenders, Specialists }\end{array}$ & \\
\hline
\end{tabular}




\section{Table 7: An occupation and motivational based typological model for categorizing food criminals with emphasis on the meat trade.}

\begin{tabular}{|c|c|}
\hline Category 1 - Industry Insiders & Description of modus operandi and vivendi \\
\hline Rogue and Criminal Farmers & $\begin{array}{l}\text { Generally, Farmers are conservative and do not have a criminal mentality. They may possess a 'Farmers mentality' or pragmatic 'hard headed' } \\
\text { approach to business and to making money. They abhor waste and actively pursue money making opportunities, or to break even financially. This } \\
\text { is a mix of ideological, professional and occupational nouse (Spink and Moyer 2011c). A small number of farmers can be classified as rogue farmers } \\
\text { (Smith 2004; Smith and McElwee 2013) and will knowingly conspire to pass otherwise wasted food products into the extended food supply chain. } \\
\text { They may actively conspire with others to steal animals for profit or fraudulently report animals stolen. Alternatively, they may launder stolen animals } \\
\text { into their flock or through their farm shop; fraudulently label food as being from another source. They may deal direct to rogue butchers and } \\
\text { restaurateurs or to trusted members customers. Rogue farmers take advantage of opportunity, whereas the criminal farmer repeatedly engages in such } \\
\text { acts. They are difficult to interdict because they operate from the privacy of their own farms and normally do not come to the attention of the } \\
\text { authorities. The farmer possesses specialist insider knowledge of farming and of the food industry. }\end{array}$ \\
\hline $\begin{array}{l}\text { Rogue Entrepreneurs and Small } \\
\text { Businessmen }\end{array}$ & $\begin{array}{l}\text { This smaller more discrete category, consists of entrepreneurs and small-businessmen actively engaged in the food trade or associated occupation. It } \\
\text { may consist of rural shopkeepers and traders who deal directly with farmers and restaurateurs. They may own a store apparently unconnected to } \\
\text { farming or the food industry but may sell food fraudulently. They may be hauliers or plant-hire specialists who earn additional income by transporting } \\
\text { stolen animals or hiring plant to the criminals. }\end{array}$ \\
\hline Rogue Butchers and Meat Traders & $\begin{array}{l}\text { These bear the least risk of all food criminals because unless caught in the act of exchanging / purchasing they can launder the stolen / fraudulent } \\
\text { meat directly into their businesses. }\end{array}$ \\
\hline Specialist Workers & $\begin{array}{l}\text { Are ex-farm workers or labourers with knowledge of farming practices and insider knowledge of how to deal with animals and farm-machinery. } \\
\text { Likewise, many rural or urban worker have experience of farm work. They extract 'cash-in-hand' payments. }\end{array}$ \\
\hline Category 2 - Industry Outsiders & Description of modus operandi and vivendi \\
\hline Criminal Mafias and Cartels & $\begin{array}{l}\text { These have little or no direct association with the business or trade being investigated. They will be organizers and financiers. They may be 'sleeping } \\
\text { partners' in the business or may have infiltrated it via threats or blackmail. The category contains businessmen with no criminal records who have to } \\
\text { be treated sensitively by the authorities making it an extremely difficult category to investigate. }\end{array}$ \\
\hline Organized Crime Groups & $\begin{array}{l}\text { Consists of organized criminals who are not traditional 'organized crime groups' but who seek the lucrative profits. They may not initially possess } \\
\text { the necessary knowledge of farming or the food trade and tend to be more opportune and easier to investigate because they are known to the police. }\end{array}$ \\
\hline Disorganized Criminals & This opportunist group are easier to interdict because they are predatory and have no contacts with the trade. \\
\hline Criminal Labor & criminal labor to rogue farmers and organized crime groups. \\
\hline
\end{tabular}




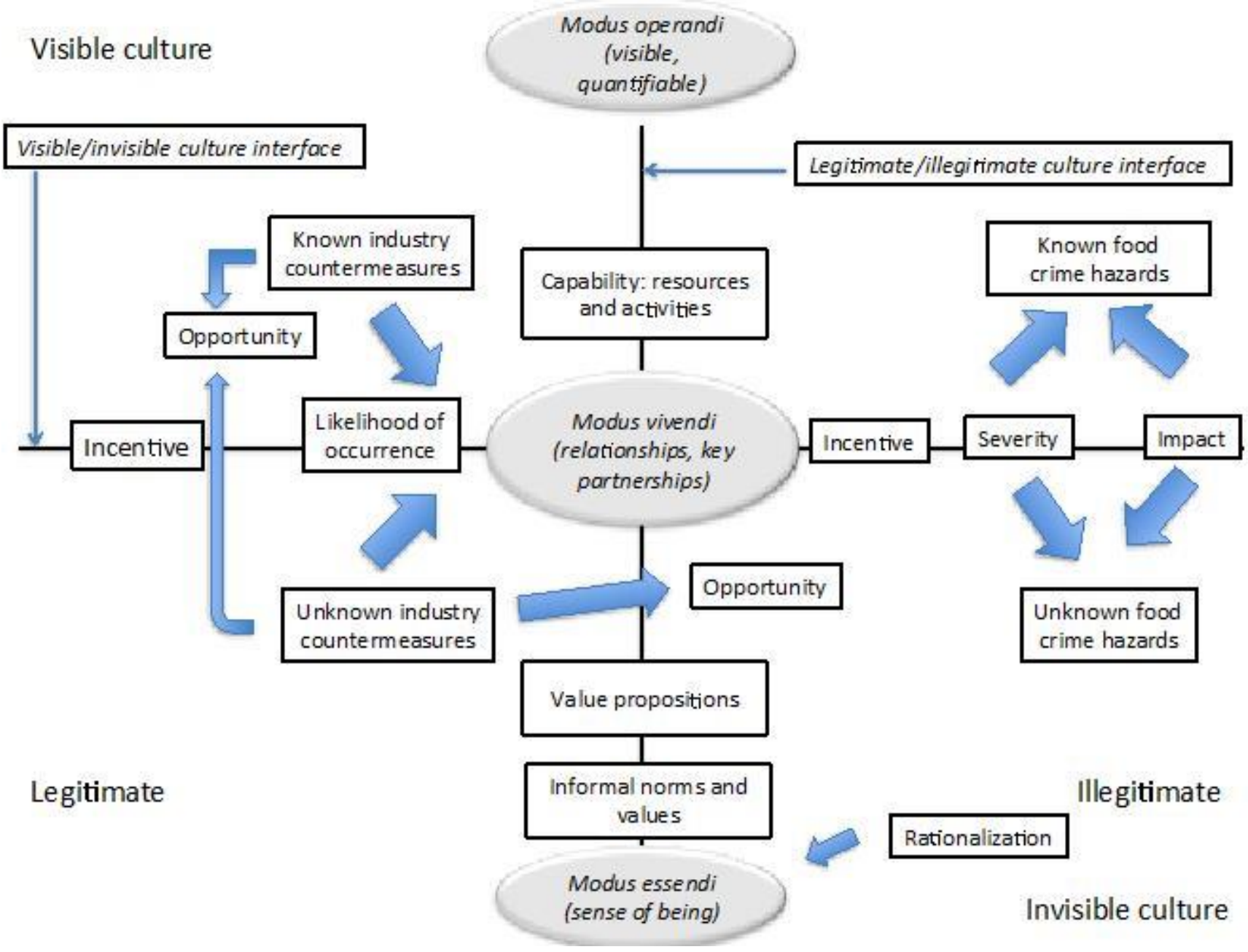

Figure 1: Food crime organizational typology framework 